\title{
Comparative Research on Contemporary American and Japanese Funds Investment in Preschool Education
}

\author{
Lina Zhang \\ Teachers' College Shenyang University \\ Shenyang, China
}

\author{
Jing Jin \\ Teachers' College Shenyang University \\ Shenyang, China
}

\begin{abstract}
In order to improve the charges standard system of Chinese preschool education for its fair development, this paper made the comparison between the preschool educational funding in America and Japan through the method of literature from the aspect of funds sources and investment policy. The enlightenment to Chinese preschool educational expenditure from these research efforts was that: to broaden the funding sources or preschool educational expenditure, to legally ensure the funds investment and to increase the educational expenditure subsidy of private kindergartens.
\end{abstract}

Keywords—preschool education; funds investment; policy

\section{CONCEPT DEFINITION}

\section{A. Preschool education}

Preschool education has the broad sense and narrow sense. The former one refers to the conservation and education that infants under the age of 6 or 7 receive. And the latter one aims at that received by the infants aged from 3 years old to 6 or 7 years old.

\section{B. Public finance}

Public finance means that a country (or government) centralizes part of social resources to provide public goods and service for the market and satisfy the allocation or economic behavior needed by the public.

\section{THE STATUS QUO OF AMERICAN FUNDS INVESTMENT IN PRESCHOOL EDUCATION}

\section{A. Sources of American preschool educational expenditure}

1) It is mainly from the federal and state government grants

Department of Health and Human Service in the federal government is charge of American Head Start and Early Head Start. The first initiative was implemented from the midterm of the 1960s, whose subsidy object is the infants aged between 3 and 5 years old from poor families. Its basic target was to make these children get rid of high fees for the preschool education. And the Early Head Start was implemented in the 1990s in America, which expanded the original subsidy objects to infants aged between 2-5 years old, and the large quantity of funds input within three years increased nearly 40 times than that in the plan, reaching $\$ 8.1$ billion in $2012^{[3]}$. In addition, this department is responsible for the fund program for infants' childcare and development, and its assistance object is those infants whose parents' income is lower than the 85 percent of the minimum income regulated by all the states.

Federal education department is charge of the program of Title regarding the school as its subsidy object. And the allocation standard is the proportion of infants with poor economy. Besides, it is also responsible for even start project, aiming at improving the literary capacity of families.

Since the 21st century, the federal government has provided more than $\$ 20$ billion for the education and life of poor families and helped over 20 million infants receive education. Also, parents and teachers' teaching abilities have been greatly improved and the research has achieved abundant results. More rational educational standard has been established, having promoted the development of American preschool education.

2) The investment of American federal and state government in preschool educational expenditure has showed the regional differences.

Due to the factors of natural resource and population, the economic and development levels among American states exist some difference. Although every student has the same right to get educated in American law, the economic and development level in some areas has limited the tax development, causing the difference between its educational expenditure and other regions. In order to make a balance, the federal government gave more educational expenditure to the less-developed areas than those developed areas. For instance, Virginia received the investment of $\$ 112.45$ million from the federal government in 2011, and per capita supported amount of infants is about \$525, while the investment in Mississippi in the same year was $\$ 176.8$ million and per capita financial support of infants is $\$ 2,062$, more than three times than that in Virginia. According to the survey of United States Department of Commerce, per capita GDP in Virginia in 2011 is 1.6 times that in Mississippi ${ }^{[1]}$. It is obvious that federal preschool education funding policy pays more attention to the investment of less-developed areas.

The difference also was showed in the aspect of the subsidy project and priority. Some state governments tended 
to give more subsidies to the certified institutions to encourage the childcare and conservation commission to develop in a high quality direction. However, it had a completely opposite effect on the institution that had the desire to be certified but lacked enough money. The state government invested far more in preschool education than nursery, so the fees that families spent on nursery was far more that in education, nearly reaching the proportion of 60 percent to 23 percent. In addition, most private foundation or charities tended to encourage the regional innovative research.

\section{B. American funding policy for preschool education}

In the United States, the preschool education justice is mainly achieved by the federal government though the method of legislation.

U.S. Congress launched the project of Early Head Start in the mid-1960s to provide poor children with the opportunity of preschool education. And the infants at special families have been attached importance to since 1970. The Education of All Handicapped Children Act was issued in the mid-1970, formulating personal education scheme based on the real condition, so as to satisfy the demands of special children. And the Head Start Act issued by American government at the beginning of the 1980s explicitly formulated the use of Early Head Start in the funds allocation amount and items. Among them, the federal funds should reach eight percent of required expenditure in the project, and the use of funds should serve the education and health of handicapped infants and poor infants.

In the mid-1990s, the subsidy object of this project covered pregnant women and young children. Aiming at this condition, the Obama administration increased the investment of preschools educational funding, not only compensating special children, but also strengthening the support and subsidy for weak preschool education projects. At the beginning of the 21st century, Early Learning Opportunity Act issued by the American federal government clearly stated that the fiscal subsidy for infants' education should be constantly increased. The issuing of this law has accelerated the research on children's education scheme and the emphasis degree of society on children education. President Bush particularly singed No Child Left Behind for children's access to fair education ${ }^{[2]}$. The federal government has focused on the appropriation since the act issued in the 19070s, and the number is increasing annually. The appropriation money in the mid-1980s reached about $\$ 1$ billion, and it has increased fivefold in the 21st century and kept the trend of relatively rapid growth.

\section{The STATUS QUO OF JAPANESE FUNDS INVESTMENT IN PRESCHOOL EDUCATION}

\section{A. Sources of Japanese preschool educational expenditure}

Japanese preschool educational expenditure mainly consists of the three parts: the country, local government and parents. Japanese preschool education isn't the part of compulsory education, and the biggest part of three investments is the allocation from local government. In general, parents afford rather low educational expenditure, but rather high in private kindergartens.
In Japan, national kindergartens belong to the national university education system, occupying 0.3 percent, whose expenditure is offered by the nation; while public kindergartens are subordinate to public primary schools, taking the proportion of 40.7 percent, whose expenditure is supported by the local government. More than half of Japanese private kindergartens can receive the government subsidy, including the institution subsidy and infants subsidy. The former can satisfy the facility demands and various affairs, in which the nation is responsible for one half and the local government is charge of about one third to one quarter ${ }^{[3]}$. The benefits that infants' families receive belong to infants subsidy, and the government will reduce their educational expenditure and other fees for private kindergartens according to the real condition of families. What's more, Japanese childcare will be subsidized by the nation, not stable, though. There will be more subsidies if the national financial budget is good, vice versa.

Japanese public finance plays a positive role in the responsibility of the government to assume the preschool education, increasing the investment of public expenditure in preschool education. For example, the public funding of preschool education in recent years have been constantly increasing, although the rate is rather slow. Because of the severe aging in Japan and reduced population of teenager, the absolute amount of preschool education financial investment is still very large.

\section{B. Japanese funding policy for preschool education}

After the War II , preschool education has been paid full attention to in Japan, and a series of legislative countermeasures have been adopted, greatly promoting the rapid development of Japanese preschool education.

Japanese government has formulated the charges standard of public kindergartens in the form of law. The nation and local government will support most of preschool expenditures, and the related charges will change according to the individual income tax paid by the parents. The conservation commission adopts the same charge method, namely, the higher parents' income means the higher charges, vice versa. Such method can play a role in narrowing the gap between the rich and the poor. In addition, these fees are not directly paid to kindergartens, but allocated by the government to the welfare departments. So children will be regarded equally in kindergartens, for they get the same allocation from the government department. It can balance the social wealth gap and maintain social stability, which is more effective than forcing kindergartens to reduce the tuition fee.

IV. The ENLIGHTENMENT OF AMERICAN AND JAPANESE PRESCHOOL EDUCATIONAL EXPENDITURE TO OUR COUNTRY

Chinese preschool education has acquired better development and increasing popularity since the reform and opening-up. However, preschool education is still the weak part in various educations in general. The insufficient educational funding and educational resource shortage have been the prominent problems. It is obvious from the comparison between American and Japanese preschool educational funning that these two countries highly emphasize 
the development of preschool education and ensured the preschool educational funds investment through the law. There are lots of experiences deserved to learn.

\section{A. To broaden the funding sources for preschool education}

Insist on the method of government-oriented and multiparticipation to raise the preschool educational expenditure. The participation of market and society must be emphasized to promote the service and supply method of multi-lateral parts. The preschool educational funding should involve enterprises, folk groups and social organization. The government is supposed to create environment condition to promote the transformation of preschool educational funding from single part to multilateral parts. Such method can not only compensate the insufficiency of government financial investment, but also fully mobilize the support of society and market.

\section{B. To legally ensure the funds investment in preschool education}

It is key to formulate rational laws and regulations of preschool education for its sound development. The funds investment should be based on good legislation and ensure its legal investment. Although the Education Act issued and implemented in 1995 clearly stipulated that "China will establish the system oriented with financial allocation and assisted with other various methods to raise educational expenditure", there is not explicit regulations and pertinence for the preschool educational funding. At present, there is still no specific Preschool Education Law in China, and even no particular law regulations with the preschool equation investment that is very important for the development of preschool education. Therefore, only by the specific law making can the successful development of preschool education be ensured and its justice is truly realized.

\section{To increase the educational expenditure subsidy of private kindergartens}

The two-child policy has been implemented from 1st, January, 2016 in China, which will lead to a number of children facing the preschool education in kindergartens in two or three years. While private kindergartens are taking a rather large proportion in China, and the public kindergarten is limited in number. In order to better solve the supplydemand conflict of preschool education, the government should increase the related funds investment and enlarge the funds subsidy for public kindergartens to promote the fair development of preschool education. On the one hand, more public kindergartens should be established and financial subsidy for the countryside and poverty-stricken areas should be ensured; on the other hand, the education subsidy of private kindergartens should be increased, and the subsidy fees should be allocated to the welfare departments from the government, not directly collected by kindergartens ${ }^{[5]}$. Such method can effectively narrow the social wealth gap and promote the fair development of preschool education.

\section{CONCLUSION}

From the comparative study on American and Japanese preschool educational funds investment, we can learn that: to broaden the funding sources or preschool educational expenditure, to legally ensure the funds investment and to increase the educational expenditure subsidy of private kindergartens. The writer is in the hope of Chinese preschool educational funding model can be further reformed and improved on the research basis, and the preschool education can be better developed.

\section{REFERENCES}

[1] Chen Houyun and Fang Ming. The attention of the United States to the development of preschool education and the enlightenment to China[J]. Studies In Preschool Education, 2001 (2)

[2] Sha Li, Pang Lijuan and Liu Xiaorui. To strengthen the responsibility of government in the development of preschool education through the method of legislation-American experience and enlightenment to China[J]. Studies In PreschoolEducation, 2007 (2)

[3] Liu Tian'e. Characteristics of modern Japanese preschool education and the enlightenment to China[J]. Journal of Nanchang Hangkong University (the edition of social science), 2012 (2)

[4] Wang Xin, The promotion of Japanese parental support policy and the enlightenment to China[J]. Preschool Education (the edition of educational science), 2007 (1)

[5] Gu Zhongyu, Zhang Wenling and Wang Qi. The strategy and enlightenment of private kindergartens developed in America and Japan[J]. Educational Science, 2006 